\title{
KEEFEKTIFAN PELAKSANAAN MANAJEMEN BERBASIS SEKOLAH DI SDN PERCOBAAN 2 DAN SDN NGRINGIN KECAMATAN DEPOK KABUPATEN SLEMAN
}

Listijaningsih, Udik Budi Wibowo

SDN Ngringin Depok Sleman, PPS UNY

liesti_21@yahoo.co.id, yube2u@yahoo.com

\begin{abstract}
Abstrak
Penelitian ini bertujuan untuk mengetahui keefektifan pelaksanaan Manajemen Berbasis Sekolah di SDN Percobaan 2 dan SDN Ngringin Kecamatan Depok, Kabupaten Sleman. Penelitian ini menggunakan pendekatan kualitatif dengan metode studi kasus (case study). Penelitian diadakan di SDN Percobaan 2 dan SDN Ngringin. Subjek penelitian adalah kepala sekolah, guru, dan karyawan untuk dijadikan informan penelitian. Teknik pengumpulan data yang digunakan adalah wawancara, observasi, dan dokumentasi. Hasil penelitian menunjukkan bahwa: (1) aspek konteks di SDN Percobaan 2 dan SDN Ngringin diperhatikan dengan sangat efektif; (2) pada aspek pendidik dan tenaga kependidikan SDN Percobaan 2 sangat efektif sedangkan, SDN Ngringin masuk kategori kurang efektif. Pada aspek pemenuhan sarana prasarana sekolah di SDN Percobaan 2 maupun SDN Ngringin sudah diupayakan secara efektif; (3) pada aspek proses pelaksanaan PBM pada dua sekolah tersebut berjalan efektif; dan (4) aspek produk, yakni budi pekerti dan kedisiplinan siswa, prestasi guru, dan prestasi sekolah di SDN Percobaan 2 dan SDN Ngringin sudah berhasil dengan efektif.
\end{abstract}

Kata kunci: efektivitas sekolah, manajemen berbasis sekolah

\section{THE EFFECTIVENESS OF THE IMPLEMENTATION OF SCHOOL-BASED MANAGEMENT AT SDN PERCOBAAN 2 AND SDN NGRINGIN IN DEPOK DISTRICT, SLEMAN REGENCY}

Listijaningsih, Udik Budi Wibowo

SDN Ngringin Depok Sleman, PPS UNY

liesti_21@yahoo.co.id, yube2u@yahoo.com

\begin{abstract}
This study aimed to find out the effectiveness of the implementation of the School-Based Management at SDN Percobaan 2 and SDN Ngringin in Depok District, Sleman Regency. This study used a qualitative approach, the case study method (case study). The research was conducted in SDN Percobaan 2 and SDN Ngringin. The subjects were the principal, teachers, and employees to serve as research informants. The data were collected by using interviews, observation, and documentation. The result showed that: (1) the context aspect both the two schools are focused very effectively; (2) in the aspect of teachers and educational personnel SDN Percobaan 2 is very effective while SDN Ngringin is in the ineffective. In the aspect of infrastructure facilities available for the both two school are effectively achieved; (3) from the process aspect, the teaching-learning processes in both two schools are effective; and (4) products including the students' moral and discipline attitude, teachers' and schools' achievements, at SDN Percobaan 2 and SDN Ngringin are effectively achieved.
\end{abstract}

Keyword: school effectiveness, school-based management 



\section{Pendahuluan}

Keberhasilan pembangunan suatu bangsa ditentukan oleh keberadaan sumber daya manusia yang berkualitas. Sumber daya manusia hanya dapat dihasilkan melalui proses pendidikan yang berkualitas. Sehubungan dengan itu, upaya peningkatan mutu pendidikan menjadi strategi penting dalam mencapai keberhasilan pembangun-an nasional, seperti melalui implementasi program manajemen berbasis sekolah (MBS). Manajemen Berbasis Sekolah merupakan penjabaran dari desentralisasi politik dan pendidikan sebagaimana diatur pada UU No. 22 Tahun 1999 jo UU No. 32 Tahun 2004 tentang Pemerintah Daerah, dan UU No. 20 Tahun 2003 tentang Sistem Pendidikan Naional (Sisdiknas), yang menegaskan bahwa pengelolaan satuan pendidikan anak usia dini, pendidikan dasar, dan pendidikan menengah dilaksanakan berdasarkan standar pelayanan minimal dengan prinsip manajemen berbasis sekolah/madrasah (Pasal 51 UU Sisdiknas). Dengan aturan tersebut maka setiap sekolah berkewajiban mengimplementasikan MBS dengan harapan dapat meningkatkan kualitas prestasi lulusannya. Manajemen pendidikan persekolahan telah memasuki era otonomi sekolah yang bernama Manajemen Berbasis Sekolah (MBS). Sekolah memiliki kewenangan untuk menyusun anggaran belanja dan programprogram peningkatan mutu. Saat ini, program MBS terus berjalan dan disempurnakan dari waktu ke waktu.

Suryosubroto (2004, p. 196) menjelaskan bahwa MBS pada dasarnya merupakan strategi pengelolaan penyelenggaraan di sekolah yang menekankan pada pengerahan dan pendayagunaan sumber internal sekolah dan lingkungan secara efektif dan efisien sehingga menghasilkan lulusan yang berkualitas dan bermutu.

Dally (2010, p. 8) mendefinisikan bahwa MBS adalah model pengelolaan yang memberikan otonomi atau kemandirian kepada sekolah dan mendorong mengambil keputusan partisipasif yang melibatkan secara langsung semua warga sekolah. Berdasarkan pendapat tersebut dapat diartikan MBS yang ditandai dengan otonomi sekolah dan pelibatan masyarakat, bertujuan untuk meningkatkan efisiensi, mutu, dan pemerataan pendidikan. Peningkatan efisiensi antara lain diperoleh melalui keleluasaan mengelola sumber daya partisipasi masyarakat dan penyederhanaan birokrasi. Peningkatan mutu sekolah diperoleh melalui partisipasi orang tua terhadap sekolah fleksibilitas pengelolaan sekolah dan kelas, peningkatan profesionalisme guru dan kepala sekolah, berlakunya sistem intensif serta disinsentif. Sekolah yang menjalankan MBS berarti harus berbudaya mutu. Budaya mutu ialah semua pikiran, perasaan, dan tindakan diarahkan untuk meningkatkan mutu.

Berdasarkan definisi-definisi tersebut dapat disimpulkan peningkatan otonomi sekolah dalam pengambilan keputusan partisipasif ditujukan untuk meningkatkan kualitas sekolah. MBS membuka pintu seluas-luasnya kepada masyarakat untuk terlibat dalam proses pengambilan keputusan dalam pengelolaan pendidikan. Setiap pengambilan keputusan dalam rangka menyelesaikan masalah di sekolah harus melibatkan partisipasi dari siswa, guru, tenaga administrasi, orang tua, dan masyarakat sekitar sekolah. Pendekatan MBS ini merupakan hal baru dalam penyelenggaraan sekolah. Penerapan strategi ini memerlukan kesiapan berbagai pihak yang berkepentingan dalam melaksanakan MBS.

Partisipasi warga sekolah yang makin besar akan mendorong adanya rasa memiliki sekolah sehingga akan menguntungkan segenap warga sekolah yang mengambil peran dalam aktivitas sekolah. MBS yang ideal menerapkan pada keseluruhan aspek pendidikan melalui pendekatan sistem. Konsep ini didasarkan pada pendekatan manajemen sebagai suatu sistem. Penerapan MBS sebagai upaya peningkatan mutu sangat diperlukan, karena apabila sekolah diberi otonomi maka sekolah akan kreatif untuk meningkatkan mutu sekolah. Sekolah diberi otonomi yang berupa kewenangan dan tanggung jawab lebih besar dalam menyelenggarakan urusan-urusan sekolah. Hal yang paling pen- 
ting diperhatikan adalah jangan memandang MBS sebagai tujuan atau akhir dari sebuah perubahan akan tetapi MBS sebagai proses administratif bagi para kepala sekolah, guru untuk berbagi kemampuan, kewenangan dan tanggung jawab demi tercapainya sebuah sistem pendidikan yang lebih baik. Orang tua dan masyarakat terlibat sesuai porsinya, yaitu sebagai pelanggan pendidikan, bukan sebagai penentu atau pengambil kebijakan.

Berdasarkan uraian tersebut dapat disimpulkan bahwa konsep MBS yang dikembangkan menekankan pada pemberian kewenangan, kepercayaan, dan kemandirian kepada sekolah untuk mengelola dan mengembangkan sumber daya pendidikan dalam rangka meningkatkan mutu pendidikan di sekolah serta mempertanggungjawabkan hasilnya kepada orangtua siswa, masyarakat, pemerintah dalam koridor kebijakan pendidikan nasional. Tujuan utama MBS adalah pemberdayaan sekolah untuk secara mandiri dapat meningkatkan mutu pendidikan.

Depdiknas (2001, p. 11) menyatakan tujuan pelaksanaan MBS untuk memandirikan dan memberdayakan sekolah melalui pemberian kewenangan, pemberian tanggung jawab, pekerjaan yang bermakna, pemecahan masalah sekolah secara teamwork, variasi tugas, hasil kerja yang terukur, kemampuan untuk mengukur kinerja sendiri, tantangan, kepercayaan, didengar, ada pujian, menghargai ide-ide, mengetahui bahwa ia adalah bagian penting dari sekolah, control yang fleksibel, dukungan, komunikasi yang efektif, umpan balik yang bagus, sumber daya yang dibutuhkan ada, warga sekolah diberdayakan sebagai manusia di sekolah. Berdasarkan uraian tersebut dapat diartikan bahwa sekolah merupakan unit utama pengelolaan proses pendidikan. MBS bermaksud meningkatkan kapasitas sekolah. Upaya meningkatkan kapasitas sekolah tidak hanya mempertimbangkan sumber daya yang sudah ada di sekolah, tetapi juga harus memperhatikan hubungan baik antara sekolah dan masyarakat sekitar sekolah sekaligus tempat sekolah mendapat du- kungan untuk melakukan perubahan. Artinya sekolah harus mampu memobilisasi sumber daya yang ada di sekolah serta tetap mencari sumber daya lain dari masyarakat sekitar.

Sementara itu Murni \& Rivai (2012, p. 148) menyatakan bahwa tujuan MBS adalah: (1) meningkatkan mutu pendidikan melalui kemandirian dan inisiatif sekolah dalam mengelola dan memberdayakan sumber daya yang tersedia; (2) meningkatkan kepedulian warga sekolah dan masyarakat dalam penyelenggaraan pendidikan melalui pengambilan keputusan bersama; (3) meningkatkan tanggung jawab sekolah kepada orangtua siswa, masyarakat, dan pemerintah tentang mutu sekolahnya; dan (4) meningkatkan kompetensi yang sehat antar sekolah tentang mutu pendidikan yang akan dicapai.

Tujuan MBS adalah untuk memandirikan dan memberdayakan sekolah melalui pemberian kewenangan, pemberian tanggung jawab, pekerjaan yang bermakna, pemecahan masalah sekolah secara teamwork, variasi tugas, hasil kerja yang terukur, kemampuan untuk mengukur kinerjanya sendiri, tantangan, kepercayaan, ada pujian, menghargai ide-ide, mengetahui bahwa guru adalah bagian penting dari sekolah, kontrol luwes, dukungan, komunikasi yang efektif, umpan balik yang bagus, sumber daya yang dibutuhkan ada, warga sekolah diberdayakan sebagai manusia ciptaan-Nya yang memiliki martabat tinggi. Tujuan penerapan MBS untuk meningkatkan kualitas pendidikan secara umum baik itu menyangkut kualitas pembelajaran, kualitas kurikulum, kualitas sumber daya manusia baik guru maupun tenaga kerja kependidikan lainnya, dan kualitas pelayanan pendidikan secara umum. Bagi sumber daya manusia, peningkatan kualitas bukan hanya meningkatnya pengetahuan dan keterampilan, melainkan juga dapat meningkatkan kesejahteraan. Fungsi-fungsi yang dapat disentralisasi dalam MBS adalah pemberian otonomi yang lebih luas kepada sekolah agar dapat mengelola dan mengerahkan semua sumber daya dan dana, penetapan kebutuhan 
sesuai prioritas dan kemampuan, sehingga dapat mencapai tujuan dengan lancar dan berjalan efektif

Davis \& Thomas (1989, p. 48) menjelaskan bahwa sekolah yang efektif didorong dari keinginan yang kuat untuk mencapai prestasi puncak. Sekolah efektif merupakan sebuah proses yang terus berkembang menuju kondisi yang lebih baik. Keefektifan merupakan prestasi manajemen untuk berfokus pada hasil, sasaran, dan target diharapkan. Sekolah efektif sebagai sekolah yang memiliki kemampuan di dalam menjalankan fungsinya secara maksimal, baik fungsi ekonomis, fungsi sosial kemanusiaan, fungsi politis, fungsi budaya, maupun fungsi-fungsi pendidikan. Pencapaian fungsi-fungsi tersebut tidak hanya terletak pada proses yang berkualitas, akan tetapi pada semua aspek.

Zamroni (2007, p. 241) menyatakan bahwa pada sekolah efektif, seluruh siswa tidak hanya siswa yang memiliki kemampuan tinggi dalam belajar yang dapat mengembangkan diri, siswa yang memiliki kemampuan intelektualitas yang biasa juga dapat mengembangkan dirinya sejauh mungkin, apalagi jika dibandingkan dengan kondisi awal ketika mereka baru memasuki sekolah. Berdasarkan pendapat tersebut dapat diartikan bahwa pada sekolah efektif tidak hanya siswa yang berkemampuan tinggi yang dapat mengembangkan diri, siswa yang berkemampuan biasa juga dapat mengembangkan dirinya. Hal ini karena adanya manipulasi proses yang efektif sehingga meningkatkan output secara optimal. Budaya yang mendukung peningkatan prestasi adalah pola dasar asumsi, sistem nilai-keyakinan dan kebiasaankebiasaan serta berbagai bentuk produk di sekolah yang akan mendorong semua warga sekolah untuk bekerja sama yang didasarkan saling percaya, mendorong munculnya gagasan-gagasan baru, dan memberikan kesempatan untuk melaksanakan pembaharuan di sekolah.

Komariah \& Triatna (2008, p. 37) menyatakan bahwa sekolah efektif dapat diidentifikasikan sebagai sekolah yang dapat menyelenggarakan proses belajar yang efektif karena ciri khas dari lembaga sekolah adalah terjadinya proses belajar mengajar. Berdasarkan pendapat tersebut dapat diartikan proses belajar mengajar yang baik akan dapat memanipulasi input yang kurang baik menjadi input yang lebih berkualitas. Sebuah proses yang baik dapat diukur dengan indikator-indikator yang memudahkan manajemen kualitas pembelajaran.

Sekolah disebut efektif jika memenuhi beberapa indikator-indikator sebagai berikut Sergiovanni (1987) dalam Davis \& Thomas (1989, p. 6) yaitu (1) Improves test score; 2) improved attendance; (3) A generally increased number of writing and homework assignments, with the amount of homework based on the age of the students; (4) increased instructional time spent on mathematics, English, sciene, history and social sciene, foreign language, and fine arts; (5) community and parent participation; (6) student participation in extracurricular activities; (7) awards and recognition for students and teachers; (8) quality of support for students with special needs.

Berdasarkan pendapat tersebut dapat diartikan bahwa sekolah efektif dapat mengelola berbagai sumber daya yang dimiliki untuk meningkatkan efektifitas sekolah. Kepala sekolah dituntut untuk meningkatkan hubungan kerja sama dengan masyarakat khususnya orang tua siswa untuk menggali dan mengelola berbagai sumber daya yang dapat dimanfaatkan untuk meningkatkan mutu pendidikan. Dalam hal ini, implementasi MBS mendorong masyarakat sekitar sekolah untuk terlibat dalam pengambilan keputusan.

Sekolah efektif adalah sekolah yang mampu mencapai tujuan-tujuan sekolah. Tujuan-tujuan sekolah dapat terlihat dari visi dan misi kemudian diturunkan menjadi rencana operasional sekolah, rencana tahunan, semesteran sampai dengan bulanan. Rencana-rencana tersebut disertai dengan strategi-strategi untuk mencapai tujuan ataupun target-target yang telah ditetapkan. Upaya-upaya sekolah dalam bentuk rencana dan strategi tersebut akan dipelajari untuk kemudian dilihat efektifitas dalam pencapaian tujuan sekolah. Sekolah 
efektif sangat memperhatikan perbaikan kualitas pembelajaran secara berkesinambungan. Sekolah yang efektif sadar bahwa lulusan berkualitas tidak mungkin terwujud tanpa proses pendidikan yang bermutu. Keefektifan pelaksanaan MBS dapat tercapai jika sumber daya sekolah berfungsi dengan baik dalam meningkatkan mutu sekolah. Sosialisasi tentang MBS dilakukan terhadap warga sekolah, baik secara formal maupun informal sehingga MBS dapat dipahami oleh warga sekolah dengan baik. Pelaksanaan MBS yang efektif dibutuhkan organisasi yang baik, yaitu adanya penanggung jawab dan program kerja pelaksanaan MBS sesuai dengan bidang kerjanya. Penerapan MBS dilakukan secara berjenjang, mulai dari intern sekolah yaitu terhadap guru, siswa, tenaga administrasi, dilanjutkan keluar sekolah terhadap orang tua siswa dan masyarakat. Bagi sekolah yang sangat memperhatikan perbaikan kualitas dari input, proses, sampai out put, maka predikat sekolah efektif akan lebih mudah diperoleh.

Kefektifan pelaksanaan MBS secara umum cukup efektif pada aspek input, proses, maupun output. Input cukup efektif dilihat dari pemahaman visi, misi, dan tujuan sekolah, siswa, kualitas program, dan jumlah sumber daya manusia. Proses cukup efektif dilihat dari kesesuaian pelaksanaan program dengan jadwal yang telah ditentukan, partisipasi warga sekolah, kerja sama baik intra maupun ekstra sudah baik dan harmonis, kemandirian, proses akuntabilitas, proses evaluasi, dan monitoring dan keterbukaan sekolah. Output cukup efektif dilihat dari prestasi akademik maupun non akademik.

Faktor pendukung adalah kondisi sekolah yang kondusif untuk belajar, teladan dari para guru, kesejahteraan diperhatikan sehingga konsentrasi pada proses belajar mengajar berjalan baik, gagasan untuk kemajuan sekolah didukung, peran serta dan rasa memiliki sekolah warga sekolah, staf berkualitas, hubungan komunikasi yang harmonis. Faktor penghambat adalah keberadaan ruang perpustakaan yang kurang kondusif, kurangnya buku- buku bacaan untuk pengayaan siswa, laboratorium masih belum ada, dan yang terutama adalah kurangnya peningkatan terhadap pengarsipan file yang sebagian besar masih secara manual.

Pelaksanaan manajemen yang perlu ditingkatkan pada aspek konteks adalah peran serta orang tua siswa dalam perencanaan dan pelaksanaan program sekolah. Komponen manajemen yang perlu ditingkatkan pada aspek input adalah: sosialisasi, pemahaman, dan penghayatan tujuan dan sasaran sekolah; penyusunan program belum berupa perencanaan yang konkret; dan penyusunan program sekolah belum menyebutkan rencana sumber daya yang dibutuhkan. Pelaksanaan manajemen yang perlu ditingkatkan pada aspek proses adalah: pengambilan keputusan masih didominasi kepala sekolah; pemberdayaan warga sekolah belum optimal; belum ada penghargaan prestasi; keterlibatan warga sekolah dalam pelaksanaan dan pengawasan program sekolah rendah; dan akuntabilitas keuangan belum optimal. Pelaksanaan manajemen yang perlu ditingkatkan pada aspek produk adalah situasi sekolah yang kurang nyaman karena bising oleh suara kendaraan dan kebersihan di depan sekolah tertata.

Keefektifan MBS juga tidak luput dari kontribusi masyarakat, khususnya orang tua siswa terhadap pelaksanaan MBS. Dalam konteks ini, sekolah perlu mendorong partisipasi masyarakat, sementara masyarakat perlu lebih aktif memberikan masukan atau dukungan terhadap setiap tahapan pelaksanaan MBS. Kontribusi yang makin besar dari guru dan orang tua siswa dalam pelaksanaan MBS dengan sendirinya akan meningkatkan kualitas input, kualitas proses, output, dan pada akhirnya kualitas outcome. Peningkatan kualitas outcome ini pada akhirnya menguntungkan masyarakat.

Berdasarkan uraian tersebut, penelitian bertujuan untuk mengetahui keefektifan pelaksanaan Manajemen Berbasis Sekolah di SDN Percobaan 2 dan SDN Ngringin Kecamatan Depok, Kabupaten Sleman. Penelitian ini menggunakan pendekatan ku- 
alitatif dengan metode studi kasus (case study).

\section{Metode Penelitian}

Jenis, Tempat, Waktu, dan Sujek Penelitian

Penelitian ini merupakan penelitian evaluasi dan menggunakan pendekatan kualitatif. Menurut Moleong (2009, p. 6) pendekatan kualitatif bermaksud untuk memahami fenomena tentang apa yang dialami oleh subjek penelitian.

Patton (2006, p. 1) menyatakan data kualitatif awalnya belum terolah, informasi dekskriptif tentang program dan orang dalam suatu program. Adapun dalam penelitian ini untuk menganalisis keefektifan sekolah digunakan metode studi kasus (case study). Ghony \& Almanshur (2012, p. 62) mendefinisikan studi kasus (case study) adalah penelitian yang diarahkan untuk menghimpun data, mengambil makna, dan memperoleh pemahaman dari suatu kasus. Studi kasus bertujuan untuk mengembangkan metode kerja yang dianggap paling efisien. Penelitian kasus lebih spesifik dan mendalam yang berhubungan dengan proses penelitian, penelitian kasus melalui proses siklus yang ada dalam sampel secara keseluruhan, penelitian kasus tidak untuk digeneralisasi.

Penelitian ini dilakukan di SDN Percobaan 2 dan SDN Ngringin Kecamatan Depok Kabupaten Sleman. Dilaksanakan pada bulan Oktober 2013 sampai dengan bulan Januari 2014.

Subjek penelitian adalah kepala sekolah, guru, karyawan, orang tua siswa dan siswa. Masing-masing subjek diteliti sehubungan dengan tugasnya sesuai dekskripsi pekerjaan yang ada. Sehingga dipilih kepala sekolah, guru, dan staf administrasi sekolah untuk dijadikan informan penelitian. Cara penelitian yaitu dengan mengunjungi kantor untuk menemui kepala sekolah, guru, dan karyawan guna melakukan penelitian. Subjek penelitian ditemui di tempat aktifitas masing-masing agar didapatkan data sebenarnya. Observasi terhadap subjek juga dilakukan agar didapatkan data yang lengkap.
Teknik Pengumpulan Data dan Teknik Analisis Data

Teknik pengumpulan data yang digunakan adalah: (1) observasi, untuk mengambil data meliputi: tenaga pendidikan, sarana, prasarana, dan proses belajar mengajar. Untuk melakukan observasi, maka telah disusun pedoman observasi, (2) wawancara, untuk mengumpulkan data tentang implementasi fungsi-fungsi manajemen dalam: manajemen sumber daya manusia, pendanaan, maupun fasilitas, (3) analisis dokumen, untuk mengambil data visi dan misi, kurikulum pendidikan, karakteristik sekolah, dokumentasi rencana strategis, laporan tahunan sekolah, prestasi akademik dan non akademik siswa, data guru, dan data sekolah. Instrumen pengumpulan data yang digunakan adalah (1) pedoman wawancara, (2) lembar observasi dan (3) lembar dokumentasi.

Data yang terkumpul dianalisis dengan analisis deskriptif yaitu dideskripsikan dan diambil kesimpulan tentang masing-masing komponen dan indikator berdasarkan kriteria yang ditentukan. Data dari hasil wawancara dan dokumentasi dianalisis secara kualitatif dengan teknik deskriptif kualitatif. Teknik analisis kualitatif yang digunakan adalah model interaksi dari Miles \& Huberman (1992, p. 16), meliputi: (1) pengumpulan data, (2) reduksi data, (3) penyajian data dan (4) pengambilan kesimpulan. Keabsahan data dilakukan dengan triangulasi dan bahan referensi.

\section{Hasil Penelitian dan Pembahasan}

Keefektifan pelaksanaan MBS di SDN Percobaan 2 dan SDN Ngringin ditinjau dari aspek Konteks.

Keefektifan pelaksanaan Manajemen Berbasis Sekolah di SDN Percobaan 2 dan SDN Ngringin ditinjau dari aspek konteks. Aspek konteks dilakukan pada tahap penjajagan untuk menghasilkan informasi untuk keputusan perencanaan. Aspeks konteks melihat tentang visi misi lembaga, dan harapan masyarakat terhadap sekolah. 
Berdasarkan Tabel 1 diketahui bahwa aspek-aspek yang terkandung dalam komponen visi dan. Visi misi disusun oleh kepala sekolah, guru, dan komite sekolah. Visi dan misi sekolah disusun pada saat workshop sekolah, rapat misi, di SDN Percobaan 2 dan SDN Ngringin sudah memilikinya sekolah bersama dengan komite. Sosialisasi tentang visi dan misi mudah dipahami melalui rapat pleno, rapat sekolah, upacara maupun tulisan yang ada di papan pengumuman kelas, sehingga warga sekolah mudah untuk membacanya. Rumusan visi misi sekolah terdapat dalam dokumen sekolah di SDN Percobaan 2 dan SDN Ngringin.

Perbandingan visi dan misi SDN Percobaan 2 dan SDN Ngringin disajkan pada Tabel 1.

Tabel 1. Perbandingan Visi dan Misi

\begin{tabular}{clll}
\hline No & \multicolumn{1}{c}{ Aspeks } & \multicolumn{1}{c}{ SD N Percobaan 2 } & \multicolumn{1}{c}{ SD N Ngringin } \\
\hline 1 & $\begin{array}{l}\text { Penyusun visi dan } \\
\text { misi. }\end{array}$ & $\begin{array}{l}\text { Kepala sekolah, guru, } \\
\text { dan komite sekolah. }\end{array}$ & $\begin{array}{l}\text { Kepala sekolah, } \\
\text { guru, dan komite } \\
\text { sekolah. }\end{array}$ \\
\hline 2 & $\begin{array}{l}\text { Bagaimana visi dan } \\
\text { misi disusun. }\end{array}$ & $\begin{array}{l}\text { Workshop sekolah } \\
\text { bersama dengan } \\
\text { pengurus komite } \\
\text { sekolah. }\end{array}$ & $\begin{array}{l}\text { Rapat sekolah } \\
\text { bersama dengan } \\
\text { komite sekolah. }\end{array}$ \\
\hline 3 & $\begin{array}{l}\text { Sosialisasi visi dan } \\
\text { misi. }\end{array}$ & $\begin{array}{l}\text { Rapat pleno wali } \\
\text { murid, pada saat } \\
\text { upacara, tulisan di } \\
\text { papan sekolah dan di } \\
\text { setiap kelas. }\end{array}$ & $\begin{array}{l}\text { Ditulis di setiap } \\
\text { kelas, ruang dan } \\
\text { kantor. }\end{array}$ \\
\hline 4 & $\begin{array}{l}\text { Ada rumusan visi dan } \\
\text { misi. }\end{array}$ & $\begin{array}{l}\text { Ada. Di dokumen } \\
\text { sekolah. }\end{array}$ & $\begin{array}{l}\text { Ada. Di dokumen } \\
\text { sekolah. }\end{array}$ \\
\hline 5 & $\begin{array}{l}\text { Rumusan visi dan } \\
\text { misi. }\end{array}$ & $\begin{array}{l}\text { Mewujudkan } \\
\text { pendidikan berkualitas } \\
\text { unggul dan berbudaya } \\
\text { bangsa. }\end{array}$ & $\begin{array}{l}\text { Unggul dalam } \\
\text { prestasi, beriman, } \\
\text { terdidik dan } \\
\text { berbudaya bangsa. }\end{array}$ \\
\hline 6 & $\begin{array}{l}\text { Memiliki rencana } \\
\text { kerja sekolah. }\end{array}$ & $\begin{array}{l}\text { Rencana kerja tahunan } \\
\text { (2013-2014), jangka } \\
\text { menengah (2013- }\end{array}$ & $\begin{array}{l}\text { Rencana kerja } \\
\text { tahunan (2011- } \\
\text { 2012), jangka } \\
\text { menengah (2011- }\end{array}$ \\
& 2016), jangka panjang \\
& (2013-2020). & $\begin{array}{l}\text { 2014), jangka } \\
\text { panjang (2011- } \\
\text { 2019). }\end{array}$ \\
\hline
\end{tabular}

Nurkholis (2003, p. 78) menyampaikan bahwa pendidikan yang berkualitas harus tumbuh dan berkembang dalam arti menyediakan berbagai cara untuk menyediakan kebutuhan peserta didik. Hal ini selaras dengan visi yang dirumuskan SDN Percobaan 2 adalah mewujudkan pendidikan berkualitas, unggul dan berbudaya bangsa. Berdasarkan visi tersebut kemudian dirumuskan menjadi misi yaitu: (1) meningkatkan ketaqwaan kepada Tuhan Yang Maha Esa, (2) mengintegrasikan pendidikan budi pekerti ke semua mata pel- ajaran, (3) meningkatkan pembelajaran yang efektif dan efisien di bidang akademik dan nonakademik, (4) menyelenggarakan kegiatan ekstrakurikuler untuk mengembangkan minat, bakat, dan potensi yang dimiliki siswa, (5) melengkapi fasilitas belajar sesuai dengan kemampuan dan kebutuhan sekolah, (6) melaksanakan manajemen transparan dan akuntabilitas, dan (7) menjalin kerja sama dengan sekolah yang lain.

Visi yang dirumuskan oleh SDN Ngringin adalah unggul dalam prestasi, beriman, terdidik dan berbudaya bangsa. Misi sekolah adalah: (1) meningkatkan proses belajar mengajar, (2) meningkatkan profesionalitas tenaga kependidikan, (3) meningkatkan sarana prasarana, 4) menciptakan situasi dan kondisi yang kondusif untuk mewujudkan keamanan dan ketaqwaan, (5) meningkatkan disiplin warga sekolah, dan (6) menumbuhkan wawasan berbudaya.

Visi dan misi yang dirumuskan merupakan hasil rapat dengan komite sekolah selaku stakeholders utama yang menginginkan anaknya mempunyai tempat pembelajaran yang berkualitas. Pada aspek visi misi lembaga kedua sekolah tersebut sudah memilikinya sehingga keefektifan sekolah dilihat dari visi misi dikategorikan sangat efektif.

SDN Percobaan 2 dan SDN Ngringin memiliki rencana kerja sekolah. Rencana kerja SDN Percobaan 2 adalah program peningkatan mutu pendidikan, program perbaikan sarana, program peningkatan sumber daya manusia, dan program kesejahteraan. Rencana kerja sekolah dilaksanakan dalam rencana kerja tahunan yaitu tahun ajaran 2013/2014-2014/2015, rencana kerja jangka menengah tahun ajaran 2013/2014-2016/2017, dan rencana kerja jangka panjang tahun ajaran 2013/2014$2020 / 2021$. Rencana kerja yang ada di SD $\mathrm{N}$ Ngringin adalah mengintensifkan pembelajaran sekolah, peningkatan mutu pendidikan, menyelenggarakan kegiatan ekstrakurikuler, dan perbaikan sarana. Rencana kerja sekolah dibagi dalam rencana kerja kerja tahunan yaitu tahun ajaran 
2011/2012-2013/2014, rencana kerja jangka menengah yaitu tahun ajaran 2011/20122014/2015, dan rencana kerja jangka panjang 2011/2012-2019/2020.

Perbandingan harapan masyarakat terhadap sekolah di SDN Percobaan 2 dan SDN Ngringin terlihat pada tabel 3 berikut. Pada aspek harapan masyarakat terhadap sekolah diketahui bahwa dua sekolah tersebut telah memenuhi sehingga apa yang dirumuskan oleh sekolah sudah merepresentasikan harapan masyarakat. Harapan masyarakat pada sekolah adalah menginginkan anak-anak mereka mendapatkan sekolah yang berkualitas. Kebutuhan masyarakat terhadap sekolah tercermin adanya masukan dari masyarakat, dan keterlibatan komite. Masyarakat memberikan masukan yang positif kepada sekolah untuk kemajuan pendidikan.

Perbandingan harapan masyarakat terhadap sekolah di SDN Percobaan 2 dan SDN Ngringin disajikan pada Tabel 2.

Tabel 2. Perbandingan Harapan Masyarakat terhadap Sekolah.

\begin{tabular}{|c|c|c|c|}
\hline No & Aspek & SD N Percobaan 2 & SD N Ngringin \\
\hline 1 & $\begin{array}{l}\text { Kebutuhan } \\
\text { masyarakat } \\
\text { terhadap } \\
\text { sekolah. }\end{array}$ & $\begin{array}{l}\text { Sekolah } \\
\text { mendapatkan } \\
\text { masukan dari } \\
\text { masyarakat. }\end{array}$ & $\begin{array}{l}\text { Tercermin dari } \\
\text { adanya } \\
\text { keterlibatan } \\
\text { komite. }\end{array}$ \\
\hline 2 & $\begin{array}{l}\text { Harapan } \\
\text { masyarakat } \\
\text { terhadap } \\
\text { sekolah. }\end{array}$ & $\begin{array}{l}\text { Dilihat dari } \\
\text { animo pendaftar } \\
56: 152=36,84 \% \\
\text { yang diterima. } \\
\text { Menolak } 63,16 \% \\
\text { pendaftar. }\end{array}$ & $\begin{array}{l}\text { Dilihat dari } \\
\text { animo pendaftar } \\
28: 35=80 \% \text { yang } \\
\text { diterima. } \\
\text { Menolak } 20 \% \\
\text { pendaftar. }\end{array}$ \\
\hline
\end{tabular}

Pada dua sekolah yang dibandingkan hampir semua aspek terpenuhi. Perbedaan yang menonjol adalah pada jumlah pendaftar untuk masuk bersekolah, dimana SDN Percobaan 2 mempunyai pendaftar 152 calon siswa, dan yang diterima 56 siswa. Hal ini terlihat dari animo pendaftar ada $56: 152=36,84 \%$ yang diterima dan menolak $63,16 \%$ pendaftar. Sedangkan SDN Ngringin yang menolak $20 \%$ calon siswa. Hal ini dilihat dari animo pendaftar $28: 35=80 \%$ yang diterima dan menolak $20 \%$ pendaftar.
Keefektifan Pelaksanaan MBS di SD N Percobaan 2 dan SD N Ngringin ditinjau dari Aspek Input.

Aspek input dilakukan pada tahap awal menghasilkan informasi untuk keputusan penentuan strategi pelaksanaan program. Aspek input melihat bagaimana kondisi siswa, guru, sarana prasarana, kurikulum dan situasi sekolah. Perbandingan aspek input yang ada di SDN Percobaan 2 dan SDN Ngringin disajikan pada Tabel 3.

Tabel 3. Perbandingan Siswa, Pendidik dan Tenaga Kependidikan

\begin{tabular}{clll}
\hline No & \multicolumn{1}{c}{ Aspek } & SD N Percobaan 2 & \multicolumn{1}{c}{ SD N Ngringin } \\
\hline 1 & $\begin{array}{l}\text { 100\% siswa mempunyai } \\
\text { buku pelajaran yang lengkap } \\
\text { untuk setiap mata pelajaran. }\end{array}$ & $\begin{array}{l}\text { Buku pelajaran } \\
\text { tersedia dan } \\
\text { lengkap. }\end{array}$ & $\begin{array}{l}\text { Buku pelajaran } \\
\text { tersedia dan lengkap. }\end{array}$ \\
\hline 2 & $\begin{array}{c}\text { Membuat program tahunat, } \\
\text { semester, silabus, RPP. }\end{array}$ & $\begin{array}{l}\text { Semua guru sudah } \\
\text { membuat. }\end{array}$ & $\begin{array}{l}\text { Semua guru sudah } \\
\text { membuat. }\end{array}$ \\
\hline 3 & Tenaga pendidik terpenuhi & Cukup dari sisi & Belum. Untuk guru \\
& dan sesuai kualifikasi. & kuantitas tetapi ada & kelas masih kurang 2 \\
& & yang belum sarjana. & orang. \\
\hline 4 & Ada tenaga administrasi. & Ada 2 orang & Ada 1 orang. \\
\hline
\end{tabular}

Komariah \& Triatna (2008, p. 43) menjelaskan keberadaan sekolah sangat diharapkan staf sebagai lembaga yang memberi harapan banyak terhadap profesi dan kehidupan. Oleh karena itu sebagai suatu lembaga yang menghadapi kepentingan orang banyak, bahkan kepentingan utama dalam pembangunan suatu bangsa, maka sudah selayaknya apabila sekolah berfokus pada pengembangan sumber daya manusia. Proses pendidikan sangat menentukan kualitas sekolah. Prestasi belajar murid dapat lebih meningkat.

Pada Tabel 3 tersebut terdapat perbedaan antara dua sekolah. Perbedaan yang menonjol adalah pada jumlah ketersediaan guru dan tenaga administrasi. Ketersediaan guru dan tenaga kependidikan SDN Percobaan 2 lebih baik dibandingkan daripada SDN Ngringin. Jumlah guru SDN Percobaan ada 28 orang, dengan kualifikasi sarjana bahkan ada yang sudah S2. Kepala sekolah berstatus Pegawai Negeri Sipil mempunyai kualifikasi S2, guru PNS berjumlah 18 orang, guru tidak tetap ada 6 orang, dan pegawai tidak tetap ada 3 orang. Sedangkan SDN Ngringin berjum- 
lah 18 orang dengan kualifikasi sarjana dan ada yang belum sarjana. Kepala sekolah berstatus Pegawai Negeri Sipil dan mempunyai kualifikasi sarjana, guru berstatus Pegawai Negeri Sipil ada 8 orang, guru tidak tetap ada 5 orang, dan pegawai tidak tetap ada 4 orang. Adanya jumlah guru yang belum memadai tersebut, maka sulit bagi sekolah untuk menyediakan sekolah yang berkualitas karena kekurangan guru akan berdampak langsung pada kualitas pembelajaran yang kurang sempurna.

Perbandingan aspek sarana prasarana SDN Percobaan 2 dan SDN Ngringin disajikan pada Tebl 4.

Tabel 4. Perbandingan sarana prasarana

\begin{tabular}{|c|c|c|c|}
\hline No & Aspek & SD N Percobaan 2 & SD N Ngringin \\
\hline 1 & $\begin{array}{l}\text { Memiliki ruang kelas, } \\
\text { laboratorium, } \\
\text { perpustakaan, UKS, } \\
\text { tempat ibadah. }\end{array}$ & $\begin{array}{l}\text { Memiliki dengan } \\
\text { lengkap dan berfungsi } \\
\text { baik. }\end{array}$ & Memiliki. \\
\hline 2 & $\begin{array}{l}\text { Memiliki ruang } \\
\text { pimpinan, ruang guru. }\end{array}$ & $\begin{array}{l}\text { Memiliki dengan } \\
\text { lengkap dan berfungsi } \\
\text { baik. }\end{array}$ & $\begin{array}{l}\text { Memiliki lengkap } \\
\text { dan berfungsi baik. }\end{array}$ \\
\hline 3 & $\begin{array}{l}\text { Memiliki kamar } \\
\text { mandi dan we yang } \\
\text { sesuai dengan jumlah } \\
\text { siswa. }\end{array}$ & $\begin{array}{l}\text { Memiliki dengan } \\
\text { lengkap dan berfungsi } \\
\text { baik. }\end{array}$ & $\begin{array}{l}\text { Memiliki dengan } \\
\text { lengkap dan } \\
\text { berfungsi baik. }\end{array}$ \\
\hline 4 & $\begin{array}{l}\text { Memiliki tempat } \\
\text { bermain, olahraga dan } \\
\text { ruang sirkulasi. }\end{array}$ & $\begin{array}{l}\text { Taman bermain dan } \\
\text { tempat olahraga jadi } \\
\text { satu yakni di halaman } \\
\text { sekolah. }\end{array}$ & $\begin{array}{l}\text { Taman bermain } \\
\text { dan tempat } \\
\text { olahraga jadi satu } \\
\text { yakni di halaman } \\
\text { sekolah. }\end{array}$ \\
\hline 5 & $\begin{array}{l}\text { Memiliki tempat cuci } \\
\text { tangan di depan kelas } \\
\text { dengan air yang } \\
\text { mengalir. }\end{array}$ & $\begin{array}{l}\text { Ada dan berfungsi } \\
\text { baik. }\end{array}$ & $\begin{array}{l}\text { Ada dan berfungsi } \\
\text { baik. }\end{array}$ \\
\hline 6 & $\begin{array}{l}\text { Memiliki alat peraga } \\
\text { sesuai mata pelajaran } \\
\text { yang diajarkan. }\end{array}$ & $\begin{array}{l}\text { Lengkap: alat peraga } \\
\text { IPA, IPS, matematika, } \\
\text { kesenian, komputer. }\end{array}$ & $\begin{array}{l}\text { Lengkap: olahraga, } \\
\text { IPA, komputer. }\end{array}$ \\
\hline 7 & $\begin{array}{l}\text { Memiliki media } \\
\text { pembelajaran: } \\
\text { komputer, laptop, } \\
\text { OHP. }\end{array}$ & $\begin{array}{l}\text { Komputer } 21 \text { unit, } \\
\text { laptop } 4 \text { unit, LCD } 1 \\
\text { unit. }\end{array}$ & $\begin{array}{l}\text { Komputer } 4 \text { unit, } \\
\text { laptop } 2 \text { unit. }\end{array}$ \\
\hline 8 & $\begin{array}{l}\text { Setiap guru } \\
\text { mempunyai buku } \\
\text { pegangan wajib dan } \\
\text { pelengkap. }\end{array}$ & $\begin{array}{l}\text { Punya. Buku } \\
\text { pelengkap dari } \\
\text { perpustakaan. }\end{array}$ & $\begin{array}{l}\text { Punya. Buku } \\
\text { pelengkap tersedia } \\
\text { di perpustakaan. }\end{array}$ \\
\hline
\end{tabular}

Pada aspek ketersediaan sarana prasarana di SDN Percobaan 2 maupun SDN Ngringin diketahui sangat efektif. Buku pelajaran yang lengkap sudah tersedia di kedua sekolah tersebut. Alat-alat peraga juga sudah tersedia dan lengkap misalnya alat peraga IPA, IPS, komputer, kesenian, dan olahraga sehingga sangat efektif.

Media pembelajaran yang ada di SDN Percobaan 2 seperti komputer, laptop, maupun LCD sudah tersedia sehingga pembelajaran menjadi mudah. Begitupula di SDN Ngringin juga sudah tersedia kom- puter, laptop maupun LCD walaupun jumlahnya baru sedikit. Buku-buku referensi sudah dipunyai di kedua sekolah tersebut dan ada buku pelengkap yang tersedia di perpustakaan sehingga mendukung pengetahuan.

Perbandingan aspek penggunaan kurikulum SDN Percobaan 2 dan SDN Ngringin disajikan pada Tabel 5 .

Tabel 5. Perbandingan Kurikulum SDN Percobaan 2 dan SDN Ngringin

\begin{tabular}{clll}
\hline No & Aspek & SD N Percobaan 2 & SD N Ngringin \\
\hline 1 & $\begin{array}{l}\text { Bagaimana KTSP } \\
\text { disusun. }\end{array}$ & $\begin{array}{l}\text { Melalui loka karya } \\
\text { guru, kepala sekolah, } \\
\text { dan komite. }\end{array}$ & $\begin{array}{l}\text { Melalui workshop } \\
\text { guru, kepala } \\
\text { sekolah, komite, }\end{array}$ \\
\hline 2 & $\begin{array}{l}\text { Adanya dokumen } \\
\text { kurikulum. }\end{array}$ & $\begin{array}{l}\text { Tersedia lengkap dan } \\
\text { tersusun rapi. }\end{array}$ & $\begin{array}{l}\text { Tersedia lengkap } \\
\text { dan tersusun rapi. }\end{array}$ \\
\hline 3 & $\begin{array}{l}\text { Penjabaran SK, KD ke } \\
\text { dalam indikator- } \\
\text { indikator. }\end{array}$ & Dijabarkan & Dijabarkan \\
\hline 4 & $\begin{array}{l}\text { Mengembangkan } \\
\text { silabus. }\end{array}$ & $\begin{array}{l}\text { Semua guru } \\
\text { mengembangkan. }\end{array}$ & $\begin{array}{l}\text { Semua guru } \\
\text { mengembangkan. }\end{array}$ \\
\hline 5 & $\begin{array}{l}\text { Menentukan KKM. } \\
\text { Semua guru } \\
\text { memberikan kriteria. }\end{array}$ & $\begin{array}{l}\text { Semua guru } \\
\text { memberikan } \\
\text { kriteria. }\end{array}$ \\
\hline 6 & $\begin{array}{l}\text { KTSP menggunakan } \\
\text { prinsip kurikulum. }\end{array}$ & Sudah & Sudah \\
\hline 7 & $\begin{array}{l}\text { Ada pihak yang } \\
\text { terlibat dalam } \\
\text { pengembangan } \\
\text { kurikulum sekolah. }\end{array}$ & $\begin{array}{l}\text { Kepala sekolah, } \\
\text { komite, guru, tokoh } \\
\text { masyarakat. }\end{array}$ & $\begin{array}{l}\text { Kepala sekolah, } \\
\text { komite, guru, tokoh } \\
\text { masyarakat. }\end{array}$ \\
\hline
\end{tabular}

Tabel 5 menunjukkan bahwa Kurikulum Tingkat Satuan Pendidikan yang ada di SDN Percobaan 2 dan SDN Ngringin sudah menggunakannya. Kurikulum mengandung pengertian seperangkat rencana dan pengaturan mengenai tujuan, isi, dan bahan pelajaran serta cara yang digunakan sebagai pedoman penyelenggaraan kegiatan pembelajaran untuk mencapai tujuan pendidikan tertentu. Sedangkan KTSP adalah seperangkat rencana dan pengaturan mengenai tujuan, isi, dan bahan pelajaran serta cara yang digunakan sebagai pedoman penyelenggaraan kegiatan pembelajaran untuk mencapai tujuan pendidikan tertentu yang disusun oleh dan dilaksanakan di masing-masing sekolah. KTSP sekolah disusun melalui lokakarya guru, kepala sekolah, dan komite. Dokumen kurikulum tersedia lengkap. Hal ini terlihat pada dokumen sekolah. Penjabaran Standar Kompetensi dan Kompetensi Dasar ke dalam indikator-indikator dapat dilihat pada dokumen sekolah. Pengembang- 
an silabus dan penentuan kriteria ketuntasan minimal sudah dilaksanakan oleh guru. Prinsip pengembangan silabus diantaranya: ilmiah, relevan, sistematis, konsisten, memadai, aktual dan kontekstual, fleksibel, dan menyeluruh. KTSP yang dikembangkan sudah berdasarkan pada prinsip-prinsip sebagai berikut: (1) berpusat pada potensi, perkembangan, kebutuhan, dan kepentingan peserta didik dan lingkungannya; (2) beragam dan terpadu; (3) tanggap terhadap perkembangan ilmu pengetahuan, teknologi dan seni; (4) relevan dengan kebutuhan kehidupan; (5) menyeluruh dan berkesinambungan; (6) belajar sepanjang hayat; dan (7) seimbang antara kepentingan nasional dan kepentingan daerah. Pihak yang dilibatkan dalam pengembangan kurikulum sekolah yaitu kepala sekolah, guru, karyawan, komite, dan tokoh masyarakat.

Prinsip kurikulum harus memenuhi prinsip relevansi yang berkaitan dengan keserasian antara tujuan isi dan proses belajar siswa yang tercakup dalam kurikulum dengan kebutuhan dan tuntutan masyarakat, prinsip fleksibilitas artinya kurikulum harus bisa dilaksanakan sesuai dengan kondisi yang ada, prinsip kontinuitas mengandung pengertian bahwa perlu dijaga saling keterkaitan dan kesinambungan antara materi pelajaran pada berbagai jenjang dan jenis program pendidikan, prinsip efektifitas berkenaan dengan rencana dalam suatu kurikulum dapat dilaksanakan dan dapat dicapai dalam kegiatan belajar mengajar, dan prinsip efisiensi berhubungan dengan perbandingan antara tenaga, waktu, dan biaya yang dikeluarkan dengan hasil yang diperoleh. Setiap tujuan akan menentukan pengalaman pembelajaran.

Berdasarkan Tabel 6 pada aspek situasi sekolah di SDN Percobaan 2 dan SDN Ngringin, keamanan sekolah terlihat aman terbukti dengan adanya sudah ada ventilasi udara yang baik, ada ventilasi cahaya, sudah terpasang teralis, dan sudah ada penjaga keamanan yang siap menjaga keamanan sekolah. Kenyamanan akses sekolah mudah dilalui oleh warga sekolah, baik kendaraan roda dua maupun roda empat.
Lokasi sekolah yang jauh dari gangguan pencemaran, baik pencemaran udara ataupun pencemaran air. Keamanan sekolah di SDN Ngringin terlihat sudah terpasang teralis pada bagian jendela-jendela ataupun pada ventilasi. Cahaya yang masuk ke ruang-ruang kelas cukup terang sehingga proses belajar mengajar nyaman. Penjaga sekolah juga sudah ada sehingga sekolah menjadi aman. Kenyamanan di SDN Ngringin dapat terlihat dari jarangnya terjadi pencurian di sekolah. Akses sekolah mudah dijangkau warga sekolah baik menggunakan kendaraan roda empat maupun roda dua. Sekolah jauh dari pencemaran, baik pencemaran air maupun pencemaran udara. Sehingga untuk situasi sekolah di SDN Percobaan 2 dan SDN Ngringin dikategorikan sangat efektif.

Perbandingan aspek situasi sekolah di SDN Percobaan 2 dan SDN Ngringin disajikan pada Tabel 6 .

Tabel 6. Perbandingan aspek situasi SDN Percobaan 2 dan SDN Ngringin

\begin{tabular}{ccll}
\hline No & \multicolumn{1}{c}{ Aspek } & \multicolumn{1}{c}{ SD N Percobaan 2 } & \multicolumn{1}{c}{ SD N Ngringin } \\
\hline 1 & Keamanan & Aman. & Aman. \\
\hline 2 & Kenyamanan & $\begin{array}{l}\text { Warga sekolah nyaman } \\
\text { di sekolah. }\end{array}$ & $\begin{array}{l}\text { Warga sekolah } \\
\text { nyaman di sekolah. }\end{array}$ \\
\hline 3 & Ketertiban & $\begin{array}{l}\text { Ada tata tertib sekolah, } \\
\text { kelas, perpustakaan. }\end{array}$ & $\begin{array}{l}\text { Ada tata tertib } \\
\text { sekolah, kelas, } \\
\text { perpustakaan. }\end{array}$ \\
\hline 4 & Keindahan & $\begin{array}{l}\text { Gambar, lukisan. Ada } \\
\text { taman sekolah. }\end{array}$ & $\begin{array}{l}\text { Penataan rapi, ada } \\
\text { taman sekolah. }\end{array}$ \\
\hline 5 & Keasrian & $\begin{array}{l}\text { Lokasi sekolah teduh, } \\
\text { tidak berbau, tidak } \\
\text { bising. }\end{array}$ & $\begin{array}{l}\text { Lokasi sekolah } \\
\text { teduh, tidak berbau, } \\
\text { tidak bising. }\end{array}$ \\
\hline 6 & Kebersihan & $\begin{array}{l}\text { Bersih, tidak ada } \\
\text { sampah berserakan. }\end{array}$ & $\begin{array}{l}\text { Bersih. Tidak ada } \\
\text { sampah berserakan. }\end{array}$ \\
\hline
\end{tabular}

Keefektifan pelaksanaan MBS di SDN Percobaan 2 dan SDN Ngringin ditinjau dari aspek Proses.

Aspek proses akan melihat bagaimana kegiatan program berjalan, partisipasi peserta, nara sumber atau guru, penampilan guru dalam proses belajar mengajar, dan bagaimana penggunaan dana.

Keberhasilan program sekolah dari sisi proses dapat dilihat dalam Tabel $7 \mathrm{di}$ atas. Tabel tersebut menunjukkan dalam pertemuan yang membahas program sekolah di SDN Percobaan 2 diadakan setiap 
pertemuan dengan komite sekolah, rapat pleno sekolah yang diadakan setiap tahun, dan ketika konsultasi setiap semester. Program yang dilaksanakan sesuai dengan kebijakan pemerintah yang melibatkan warga sekolah yaitu kepala sekolah, guru, karyawan, komite dan tokoh masyarakat. Muatan lokal yang ada di sekolah adalah pelajaran bahasa jawa dan bahasa Inggris. Hal ini sudah dilaksanakan dengan baik. Dukungan finansial yang diberikan juga sudah mendukung pelaksanaan programprogram yang ada di sekolah. Kegiatan pengembangan diri di SDN Percobaan sudah dilaksanakan diantaranya pramuka, teknologi informasi, baca tulis Al Quran, bahasa Inggris.

Perbandingan kegiatan program sekolah di SDN Percobaan 2 dan SDN Ngringin disajikan pada Tabel 7.

Tabel 7. Perbandingan Kegiatan Program Sekolah

\begin{tabular}{clll}
\hline No & \multicolumn{1}{c}{ Aspek } & \multicolumn{1}{c}{ SD N Percobaan 2 } & \multicolumn{1}{c}{ SD N Ngringin } \\
\hline 1 & $\begin{array}{l}\text { Pertemuan dengan } \\
\text { stakeholders membahas } \\
\text { tentang program } \\
\text { sekolah. }\end{array}$ & $\begin{array}{l}\text { Ada. Pada saat rapat } \\
\text { komite setiap bulan. } \\
\text { Pleno setiap tahun. } \\
\text { Konsultasi setiap } \\
\text { semester. }\end{array}$ & $\begin{array}{l}\text { Setiap dua bulan } \\
\text { sekali rapat komite. } \\
\text { Pleno setiap tahun. }\end{array}$ \\
\hline 2 & $\begin{array}{l}\text { Keterlibatan pembuatan } \\
\text { program sekolah. }\end{array}$ & $\begin{array}{l}\text { Melibatkan kepala } \\
\text { sekolah, guru, } \\
\text { karyawan, komite, dan } \\
\text { tokoh masyarakat. }\end{array}$ & $\begin{array}{l}\text { Melibatkan kepala } \\
\text { sekolah, guru, } \\
\text { karyawan, komite, } \\
\text { dan tokoh } \\
\text { masyarakat. }\end{array}$ \\
& & $\begin{array}{l}\text { Bahasa jawa dan } \\
\text { bahasa Inggris. }\end{array}$ & $\begin{array}{l}\text { Bahasa jawa dan } \\
\text { bahasa Inggris, } \\
\text { karawitan. }\end{array}$ \\
\hline 3 & $\begin{array}{l}\text { Muatan lokal di } \\
\text { sekolah. }\end{array}$ & $\begin{array}{l}\text { Ada. Pramuka, } \\
\text { teknologi informasi, } \\
\text { baca tulis Al Quran, } \\
\text { bahasa Inggris. }\end{array}$ & $\begin{array}{l}\text { Ada. Drum band, } \\
\text { pramuka, } \\
\text { sepakbola. }\end{array}$ \\
\hline 4 & $\begin{array}{l}\text { Program } \\
\text { pengembangan diri. }\end{array}$ & & \\
& &
\end{tabular}

Demikian pula yang dilaksanakan di SDN Ngringin pertemuan-pertemuan yang diadakan pada saat rapat komite, rapat pleno, konsultasi setiap semester bertujuan untuk membahas program-program yang ada di sekolah. Program sekolah yang diadakan juga sudah sesuai dengan kebijakan pemerintah dan sudah melibatkan kepala sekolah, guru, karyawan dan tokoh masyarakat. Muatan lokal yang ada di sekolah yaitu bahasa jawa, bahasa inggris, dan karawitan.

Perbandingan proses belajar mengajar di SDN Percobaan 2 dan SDN Ngringin disajikan dalam Tabel 8.
Tabel 8. Perbandingan Proses Belajar Mengajar

\begin{tabular}{clll}
\hline No & \multicolumn{1}{c}{ Aspek } & SD N Percobaan 2 & SD N Ngringin \\
\hline 1 & $\begin{array}{l}\text { RPP sudah } \\
\text { menggunakan } \\
\text { prinsip penyusunan. }\end{array}$ & Sudah menggunakan. & $\begin{array}{l}\text { Sudah } \\
\text { menggunakan. }\end{array}$ \\
\hline 2 & $\begin{array}{l}\text { Pelaksanaan } \\
\text { supervisi } \\
\text { pembelajaran. }\end{array}$ & $\begin{array}{l}\text { Dilakukan oleh kepala } \\
\text { sekolah kepada guru. }\end{array}$ & $\begin{array}{l}\text { Dilakukan oleh } \\
\text { kepala sekolah } \\
\text { kepada guru. }\end{array}$ \\
\hline 3 & $\begin{array}{l}\text { Ketersediaan } \\
\text { kalender pendidikan. }\end{array}$ & Ada dan lengkap. & $\begin{array}{l}\text { Ada dan } \\
\text { lengkap. }\end{array}$ \\
\hline
\end{tabular}

Tabel 8 tersebut menunjukkan pada aspek proses pelaksanaan belajar mengajar terlihat Rencana Pelaksanaan Pembelajaran sudah menggunakan prinsip penyusunan. Prinsip penyusunan disebutkan bahwa sebelum mengajar guru harus membuat rencana mengajar dalam bentuk satuan pelajaran. Satuan pelajaran ini berisi komponen-komponen yang berhubungan dengan identitas materi pelajaran, waktu pelaksanaan, dan bagaimana dilaksanakan. Prinsip penyusunan ini sudah digunakan di SDN Percobaan 2 maupun SDN Ngringin. Proses pembelajaran yang kreatif akan memunculkan pembelajaran yang berkualitas sehingga memacu siswa untuk mendapatkan prestasi yang tinggi di sekolah. Hal yang tidak kalah penting adanya supervisi dari kepala sekolah tentang proses pembelajaran yang telah terjadi, dimana sekolah telah menjalankan prosedur supervisi secara rutin yakni sebulan sekali. Supervisi penting sekali dalam kegiatan sekolah karena bertujuan meningkatkan kualitas dan kinerja.

Kurikulum satuan pendidikan pada setiap jenis dan jenjang diselenggarakan dengan mengikuti kalender pendidikan pada setiap tahun ajaran. Kalender pendidikan adalah pengaturan waktu untuk kegiatan pembelajaran peserta didik selama satu tahun ajaran yang mencakup permulaan tahun pelajaran, minggu efektif belajar, waktu pembelajaran efektif dan hari libur.

Perbandingan dana untuk operasional sekolah di SDN Percobaan 2 dan SDN Ngringin disajikan dalam Tabel 9. 
Tabel 9. Perbandingan Dana Operasional Sekolah

\begin{tabular}{|c|c|c|c|}
\hline No & Aspek & SD N Percobaan 2 & SD N Ngringin \\
\hline 1 & $\begin{array}{l}\text { Sekolah memiliki dana } \\
\text { untuk operasional } \\
\text { sekolah. }\end{array}$ & $\begin{array}{l}\text { Ada. BOSNAS, BOSDA, } \\
\text { BOS Provinsi. }\end{array}$ & $\begin{array}{l}\text { Ada. BOSNAS, } \\
\text { BOSDA, BOS } \\
\text { Provinsi. }\end{array}$ \\
\hline 2 & $\begin{array}{l}\text { Adanya dukungan } \\
\text { finansial dari pemerintah. }\end{array}$ & $\begin{array}{l}\text { Digunakan untuk } \\
\text { membayar gaji, honor, } \\
\text { dan sudah membuat } \\
\text { RAPBS. }\end{array}$ & $\begin{array}{l}\text { Digunakan untuk } \\
\text { membayar gaji, honor, } \\
\text { dan sudah membuat } \\
\text { RAPBS. }\end{array}$ \\
\hline
\end{tabular}

Tabel 9 di atas menunjukkan bahwa pada aspek sumber dan ketersediaan dana, keduanya memang memiliki sumber dana yang sama akan tetapi SDN Percobaan 2 mempunyai jumlah anggaran yang berbeda karena mempunyai jumlah siswa yang banyak. Perbedaan ini dihasilkan dari sumber dana komite yang lebih besar dan kebutuhan sekolah juga besar. Sumber dana SDN Percobaan 2 dan SDN Ngringin berasal dari Bantuan Operasional Sekolah Nasional, Bantuan Operasional Sekolah Daerah, dan Bantuan Operasional Sekolah Provinsi. Dana Bantuan Operasional Sekolah yang diterima dari BOSNAS Rp 580.000/ anak/tahun, BOSDA sebesar Rp 130.000/ anak/tahun, dan BOS Provinsi Rp 72.100/ anak/tahun. Secara umum program Bantuan Operasional Sekolah bertujuan untuk meringankan beban masyarakat terhadap pembiayaan pendidikan dalam rangka wajib belajar 9 tahun yang bermutu. Secara khusus program Bantuan Operasional Sekolah bertujuan untuk menggratiskan seluruh siswa miskin di tingkat pendidikan dari beban biaya operasional sekolah baik di sekolah negeri maupun sekolah swasta.

Dukungan finansial dari pemerintah yang diberikan kepada sekolah dengan membayar gaji, honor, maupun kegiatankegiatan juga sudah diberikan. Rencana Anggaran Pendapatan dan Belanja Sekolah sudah dibuat oleh kedua sekolah tersebut. Pemasukan dan pengeluaran sudah tercatat dengan rapi dan sudah dilaporkan dengan rutin setiap tri wulan sekali, dan pada rapat pleno sekolah sudah dilaporkan kepada semua orang tua siswa sebagai bentuk pertanggungjawaban kepada warga sekolah.
Keefektifan pelaksanaan MBS di SDN Percobaan 2 dan SDN Ngringin ditinjau dari Aspek Produk.

Setelah melalui proses, maka selanjutnya dilakukan perbandingan pada aspek produk. Pada aspek produk untuk mengetahui keberhasilan program-program sekolah. Aspek produk menghasilkan informasi untuk keputusan kelanjutan programprogram sekolah, aspek produk juga sebagai akuntabilitas pimpinan tentang program sekolah yang menjadi tanggung jawab pimpinan kepada stakeholders.

Pada aspek produk untuk mengetahui keberhasilan program-program sekolah. Aspek produk menghasilkan informasi untuk keputusan kelanjutan programprogram sekolah, aspek produk juga sebagai akuntabilitas pimpinan tentang program sekolah yang menjadi tanggung jawab pimpinan kepada stakeholders.

Tabel 10. Perbandingan Prestasi Sekolah

\begin{tabular}{|c|c|c|c|}
\hline No & Aspek & SD N Percobaan 2 & SD N Ngringin \\
\hline 1 & Prestasi akademik & $\begin{array}{l}\text { Olimpiade MIPA } \\
\text { tingkat Kabupaten } \\
\text { dan Provinsi. }\end{array}$ & Tidak punya \\
\hline 2 & $\begin{array}{l}\text { Prestasi non } \\
\text { akademik. }\end{array}$ & $\begin{array}{l}\text { Juara bidang } \\
\text { olahraga provinsi. }\end{array}$ & Tidak punya \\
\hline 3 & Prestasi guru & $\begin{array}{l}\text { Sering mengikuti } \\
\text { diklat tingkat } \\
\text { Kabupaten, Provinsi. }\end{array}$ & Jarang \\
\hline 4 & Prestasi sekolah & $\begin{array}{l}\text { Lomba gugus inti. } \\
\text { Juara I tingkat } \\
\text { kabupaten. Tahun } \\
2011 .\end{array}$ & Tidak punya. \\
\hline 5 & $\begin{array}{l}\text { Sekolah memiliki } \\
\text { prestasi di tingkat } \\
\text { kabupaten, provinsi, } \\
\text { nasional. }\end{array}$ & $\begin{array}{l}\text { Lomba } \\
\text { perpustakaan. Juara } \\
\text { harapan I Provinsi. } \\
\text { Tahun } 2013 .\end{array}$ & Tidak punya \\
\hline 6 & Nilai Ujian Nasional & $\begin{array}{l}\text { B Indonesia: } 8,88 \\
\text { IPA: } 8,94 \\
\text { Matematika: } 8,35\end{array}$ & $\begin{array}{l}\text { B Indonesia: } 8,32 \\
\text { IPA: } 8,20 \\
\text { Matematika: } 5,75\end{array}$ \\
\hline 7 & $\begin{array}{l}\text { Rata-rata nilai Ujian } \\
\text { Nasional }\end{array}$ & 8,72 & 7,42 \\
\hline 8 & $\begin{array}{l}100 \% \text { lulus Ujian } \\
\text { Nasional }\end{array}$ & Lulus dengan baik & Lulus \\
\hline 9 & $\begin{array}{l}\text { Hasil Akreditasi } \\
\text { Sekolah }\end{array}$ & $\mathrm{A}$ & B \\
\hline
\end{tabular}

Tabel 10 menunjukkan prestasi guru maupun siswa kelihatan cukup berbeda antara SDN Percobaan 2 dengan SDN Ngringin. Berdasarkan Tabel 10 dapat diketahui bahwa prestasi siswa SDN Percobaan 2 selalu mendapatkan juara sebagai peserta olimpiade, guru mempunyai prestasi dengan adanya sering mengikuti diklat maupun seminar-seminar, nilai rata-rata ujian nasional yang tinggi. Sekolah berhasil 
mendapatkan juara I tahun 2011 dalam lomba gugus inti yang diadakan oleh Dinas Pendidikan Pemuda dan Olahraga Kabupaten Sleman. Lomba perpustakaan tingkat Provinsi mendapatkan juara harapan I tahun 2013.

Dilihat dari rata-rata nilai ujian nasional menunjukkan di SDN Percobaan 2 sebesar 8,72 lebih besar dibandingkan SDN Ngringin yang mempunyai nilai rata-rata 7,42 . Hal ini terlihat bahwa produk yang dihasilkan oleh SDN Percobaan 2 lebih baik dibandingkan dengan SDN Ngringin. Berdasarkan nilai ujian nasional per bidang studi diketahui SDN Percobaan 2 memiliki nilai ujian nasional di atas 8,00 untuk semua mata pelajaran yang diujikan. Sedangkan SDN Ngringin memiliki satu nilai mata pelajaran di bawah 8,00 yakni pelajaran matematika sebesar 5,75. SDN Ngringin belum memiliki prestasi akademik di tingkat kabupaten maupun provinsi. Prestasi non akademik belum terlihat. Prestasi guru juga belum nampak karena jarang mengikuti diklat maupun seminar. Prestasi yang diraih sekolah juga belum terlihat baik tingkat kabupaten maupun tingkat provinsi.

Dari data tersebut menunjukkan bahwa aspek produk sekolah yang tercermin dari nilai ujian nasional, di SDN Percobaan 2 mempunyai nilai rata-rata yang bagus. Perbedaan aspek produk sekolah dipengaruhi adanya proses belajar mengajar yang berbeda. Komponen utama proses yang ada dalam sistem sekolah adalah kegiatan belajar mengajar. Dalam kegiatan proses belajar mengajar yang penting diperhatikan adalah guru. Oleh karenanya guru adalah instrumen penting dalam proses belajar mengajar. Menurut Hoy \& Miskel (2001, p. 40) guru yang profesional akan menjalankan tugasnya dengan baik dan mencapai tujuan sekolah. Tercapainya tujuan sekolah berarti tercapainya efektifitas program sekolah. Perbedaan kreatifitas dan kedisiplinan guru mempengaruhi keberhasilan proses belajar mengajar. Hasil akreditasi kedua sekolah mempunyai predikat akreditasi yang berbeda. SDN Percobaan 2 menyandang predikat akreditasi A dengan sebutan amat baik, akan tetapi SDN Ngringin mendapat predikat $B$ dengan sebutan baik.

Pada aspek budi pekerti dan kedisiplinan di SDN Percobaan 2 dan SDN Ngringin dapat dilihat pada Tabel 11.

Tingkat kedisiplinan dapat dilihat dari upaya siswa menjalankan kegiatan sehari-hari di sekolah. Kegiatan siswa dari datang ke sekolah, mulai masuk kelas, menerima pelajaran dari guru, istirahat, berinteraksi dengan sesama teman, siswa dan guru, mengakhiri pembelajaran sampai pulang ke rumah masing-masing. Aktifitas pertama yang dilakukan siswa sebelum memulai pelajaran adalah berdoa. Berdoa sudah menjadi keharusan bagi siswa-siswi di SDN Percobaan 2 maupun SDN Ngringin. Selama mereka berinteraksi dengan teman sesama siswa dan guru selalu membudayakan senyum, salam, sapa sehingga memunculkan keakraban antara sesama siswa dengan siswa, dan siswa dengan guru. Kepatuhan terhadap tata tertib yang telah dibuat sekolah dilakukan oleh siswa dan guru dari kedua sekolah. Untuk memupuk rasa nasionalisme, para siswa secara rutin melakukan upacara bendera setiap hari Senin dan hari besar. Perbedaan kualitas, kreativitas dan kompetensi guru serta kepala sekolah menentukan tingkat keberhasilan proses belajar mengajar.

Tabel 11. Perbandingan aspek budi pekerti dan kedisiplinan

\begin{tabular}{llll}
\hline No & Aspek & SD N Percobaan 2 & SD N Ngringin \\
\hline 1 & Kebiasaan berdoa. & $\begin{array}{l}\text { Dilakukan setiap } \\
\text { pagi dan sebelum } \\
\text { pulang sekolah. }\end{array}$ & $\begin{array}{l}\text { Dilakukan setiap } \\
\text { pagi dan sebelum } \\
\text { pulang sekolah. }\end{array}$ \\
\hline 2 & $\begin{array}{l}\text { Budaya senyum, } \\
\text { salam, sapa. }\end{array}$ & Selalu dilakukan & Selalu dilakukan \\
\hline 3 & $\begin{array}{l}\text { Peringatan hari besar } \\
\text { agama. }\end{array}$ & Diperingati & Diperingati \\
\hline 4 & $\begin{array}{l}\text { Upacara bendera } \\
\text { setiap hari Senin dan } \\
\text { hari besar. }\end{array}$ & Selalu dilakukan & Selalu dilakukan \\
\hline
\end{tabular}

Berdasarkan hasil penelitian dapat dilakukan pembahasan pada aspek konteks tentang apa visi misi lembaga, dan apa harapan masyarakat. Bush \& Coleman (2000, p. 48) menyatakan terdapat 11 karakteristik dalam memandang sekolah efektif yaitu kepemimpinan yang profesional, visi dan misi, lingkungan belajar, konsentrasi 
terhadap proses belajar dan mengajar, pengharapan yang tinggi, dorongan positif, pengawasan kemajuan yang terjadi, hak dan kewajiban siswa, pengajaran yang tepat, suatu organisasi pembelajar, dan hubungan rumah dengan sekolah.

Perbedaan dalam hal konteks yang mencolok adalah animo pendaftar yang berbeda antara dua sekolah tersebut, yakni SDN Percobaan 2 ada 56:152 = 36,84\% calon siswa yang diterima dan menolak $63,16 \%$ calon siswa. Sedangkan SDN Ngringin ada $28: 35=80 \%$ calon siswa yang diterima, dan menolak $20 \%$ calon siswa. Para orang tua dan segenap stakeholders setuju dengan visi dan misi karena memang diikutsertakan dalam penyusunan visi dan misi tersebut. Sehingga dapat disimpulkan bahwa sekolah telah mampu merespons tuntutan masyarakat untuk diwujudkan bersama. Depdiknas (2001, p. 3) menjelaskan sekolah memiliki kewenangan yang lebih besar dalam mengelola sekolahnya sehingga sekolah lebih mandiri. Dengan kemandiriannya, sekolah lebih berdaya guna dalam mengembangkan program-program sekolah yang sesuai dengan kebutuhan dan potensi yang dimiliki.

Pada aspek konteks di SDN Percobaan 2 dan SDN Ngringin dikategorikan sangat efektif karena semua indikator sudah tercermin di sekolah. Hal ini terbukti dari visi dan misi di dua sekolah tersebut terpenuhi sehingga disimpulkan sangat mendukung. Demikian pula dalam penentuan visi misi diterapkan pengambilan keputusan partisipasif yaitu pelibatan warga sekolah secara langsung dalam pengambilan keputusan, maka rasa memiliki warga sekolah dapat meningkat. Tjiptono \& Diana (2003, p. 407) menyatakan komitmen terhadap kualitas dimulai dengan pernyataan dedikasi pada visi dan misi bersama, serta pemberdayaan semua partisipan untuk secara bersama mewujudkan visi dan misi tersebut.

Berdasarkan hasil pengumpulan data pada aspek input diketahui bahwa dari dua sekolah yang dibandingkan hampir mempunyai kesamaan pada aspek-aspek yang dibandingkan sehingga sama-sama disimpulkan sangat efektif. Fasilitas pembelajaran mulai dari: ketersediaan buku pelajaran, alat-alat peraga, alat-alat peraga, fasilitas media pembelajaran (OHP, komputer, LCD) sama-sama dimiliki oleh kedua sekolah. Depdiknas (2001, p. 23) menyatakan pengelolaan fasilitas sudah seharusnya dilakukan oleh sekolah, mulai dari pengadaan, pemeliharaan, dan perbaikan sampai pada pengembangan. Hal ini didasari oleh kenyataan bahwa sekolah yang paling mengetahui kebutuhan fasilitas, baik kecukupan, maupun kemutakhirannya terutama fasilitas yang sangat erat kaitannya secara langsung dengan proses belajar mengajar. Input sekolah dalam pendidikan adalah segala sesuatu yang harus tersedia karena dibutuhkan untuk berlangsungnya proses. Sesuatu yang dimaksud berupa sumber daya dan perangkat lunak serta harapan-harapan sebagai pemandu bagi berlangsungnya proses. Pada aspek pendidik dan tenaga kependidikan terdapat perbedaan yang cukup menonjol yaitu pada ketersediaan guru dan tenaga administrasi dimiliki sekolah. Sehingga untuk SDN Percobaan 2 dikategorikan sangat efektif, tetapi di SDN Ngringin mempunyai kategori belum efektif.

Pada aspek proses kedua sekolah dalam pertemuan dengan stakeholders masingmasing sudah terlaksana dengan baik. Pertemuan komite sekolah dilakukan secara rutin oleh kedua sekolah tersebut sehingga komunikasi tidak terhambat. Lancarnya komunikasi sangat membantu sekolah untuk menjalankan program-program sekolah bagi para siswa.

Untuk KTSP SDN Percobaan 2 dan SDN Ngringin sudah menggunakannya. Pada aspek situasi sekolah kedua sekolah sangat mendukung terbukti semua indikator keamanan sekolah, kenyamanan sekolah, ketertiban sekolah, keindahan, keasrian, dan kebersihan telah terpenuhi. Berdasarkan hasil penelitian secara umum diketahui pada aspek proses, proses belajar mengajar masuk dalam kategori efektif. Danim (2010, p. 145) menyatakan bahwa pengertian mutu mengacu pada masukan, proses, luaran, dan dampaknya. Hasil pen- 
didikan dipandang bermutu jika mampu memberikan keunggulan akademik maupun non akademik. Peningkatan kualitas proses pembelajaran pada sisi manajemen sekolah, kepala sekolah mempunyai keunggulan kedisiplinan. Hal ini sesuai dengan pendapat Dally (2010, p. 8) bahwa manajemen berbasis sekolah yang ditandai dengan otonomi sekolah dan pelibatan masyarakat. Bertujuan untuk meningkatkan efisiensi, mutu dan pemerataan pendidikan. Pada aspek proses, proses pelaksanaan belajar mengajar dari kedua sekolah dikategorikan efektif.

Pada aspek produk kedua sekolah mempunyai kategori efektif. Aspek produk yang dihasilkan yakni prestasi siswa, guru dan sekolah terlihat baik meskipun ada perbedaan di dua sekolah tersebut. Para guru di SDN Percobaan 2 mempunyai kedisiplinan yang tinggi dalam menjalankan berbagai tugas yang dibebankan kepadanya. Perbedaan kualitas, kreativitas dan kompetensi guru serta kepala sekolah menentukan tingkat keberhasilan proses belajar mengajar. Hal ini terbukti dengan keberhasilan produk-produk yang dicapai oleh dua sekolah. Bafadal (2003, p. 44) menyatakan bahwa seorang pemimpin harus mempunyai sifat-sifat pribadi yang terpuji, dan harus dapat merumuskan tujuan misalnya merumuskan visi, misi, kondisi, dan aksi yang ingin dicapai memiliki keterampilan dalam bidang yang dipimpinnya.

Untuk prestasi, baik prestasi akademik maupun non akademik SDN Percobaan 2 lebih efektif dibandingkan dengan SDN Ngringin. Terbukti di SDN Percobaan 2 prestasi akademik yang diraih mendapatkan kejuaraan olimpiade MIPA kabupaten dan provinsi, prestasi non akademik juara bidang olahraga provinsi, prestasi guru dilihat dari sering mengikuti diklat ataupun seminar, rata-rata nilai ujian nasional yang cukup bagus mencapai 8,72. Hasil akreditasi mendapatkan predikat A dengan sebutan amat baik.

SDN Ngringin belum terlihat hasil kejuaraan di tingkat kabupaten maupun provinsi. Rata-rata Ujian Nasional mencapai 7,42 dan ada satu nilai mata pelajaran di bawah 8,00 yakni pelajaran matematika sebesar 5,75. Guru jarang mengikuti diklat maupun seminar, sekolah belum mempunyai kejuaraan tingkat kabupaten, provinsi maupun nasional. Perbedaan kualitas, kreativitas, dan kompetensi guru serta kepala sekolah ikut menentukan keberhasilan proses belajar mengajar.

Berdasarkan hasil analisis di atas diketahui adanya perbedaan keefektifan produk sekolah disebabkan perbedaan komponen yang lain yakni: konteks, input dan proses. Perbedaan dalam hal konteks yang mencolok adanya animo pendaftar yang berbeda antara dua sekolah, yakni SDN Percobaan 2 ada 56:152 = 36,84\% calon siswa yang diterima, sehingga menolak $63,16 \%$ calon siswa. Sedangkan di SDN Ngringin terdapat $28: 35=80 \%$ calon siswa yang diterima, menolak $20 \%$ calon siswa. Pada aspek input perbedaan terdapat pada kuantitas dan kualitas pendidik dan tenaga kependidikan. Pada aspek proses perbedaan terdapat dalam proses belajar mengajar siswa.

\section{Simpulan dan Saran}

Simpulan

Berdasarkan hasil pengumpulan data dan pembahasan di atas, dapat disimpulkan keefektifan pelaksanaan manajemen berbasis sekolah sebagai berikut: (1) SDN Percobaan 2 pada aspek konteks mempunyai kategori sangat efektif, aspek input mempunyai kategori sangat efektif, aspek proses mempunyai kategori efektif, dan aspek produk mempunyai kategori efektif, (2) SDN Ngringin pada aspek konteks mempunyai kategori sangat efektif, aspek input mempunyai kategori kurang efektif, aspek proses mempunyai kategori efektif, dan aspek produk mempunyai kategori efektif.

Saran

Berdasarkan hasil analisis penelitian di atas, dapat diberikan saran-saran sebagai berikut: (1) SDN Percobaan 2 diharapkan dapat mempertahankan prestasi- 
nya. Sehingga sekolah dapat berkualitas dalam pembelajaran, (2) SDN Ngringin diharapkan dapat meningkatkan terus prestasi belajar para siswa sehingga prestasinya semakin meningkat. Salah satu caranya dengan melakukan studi banding dengan sekolah-sekolah yang lain, dan (3) peningkatan mutu pendidikan tidak hanya tanggung jawab sekolah. Diharapkan keterlibatan stakeholders sebagai pengguna mutu lulusan perlu ditingkatkan dalam kegiatan di sekolah.

\section{Daftar Pustaka}

Bafadal, I. (2003). Manajemen peningkatan mutu sekolah dasar: dari sentralisasi menuju desentralisasi. Jakarta: Bumi Aksara.

Bush, T. \& Coleman, M. (2000). Leadership and strategic in management in education. New Jersey: Sage Publication.

Dally, D. (2010). Suatu pendekatan dalam implementasi manajemen berbasis sekolah. Bandung: PT Remaja Rosdakarya.

Danim, S. (2010). Otonomi manajemen sekolah. Bandung: CV Alfabeta.

Davis, G.A. \& Thomas, M.A. (1989). Effective schools and effective teacher. London: Allyn and Bacon.

Depdiknas. (2001). Manajemen berbasis sekolah. Jakarta: Depdiknas.
Ghony, D. \& Almanshur, F. (2012). Metodologi penelitian kualitatif. Yogyakarta: AR-RUZZ Media.

Hoy, W.K \& Miskel, C.G. (2008). Education administration. Theory, research, and practice. Singapore: Mc-graw-Hill.

Komariah, A. \& Triatna, C. (2008). Visionary leadership, menuju sekolah efektif. Jakarta: Bumi Aksara.

Miles, B.M. \& Huberman, A.M. (1992). Analisis data kualitatif. Jakarta: Penerbit UI-Press.

Moleong, J.L. (2005). Metode penelitian kualitatif. Bandung: PT. Remaja Rosda Karya.

Murni, S. \& Rivai, V. (2012). Education management. Analisis teori dan praktik. Jakarta: PT Raja Grafindo Persada.

Nurkholis. (2003). Manajemen berbasis sekolah. Jakarta: Grasindo.

Patton, M.Q. (2006). Metode penelitian kualitatif. Yogyakarta: Pustaka Pelajar.

Suryosubroto. (2004). Manajemen pendidikan di sekolah. Jakarta: PT Rineka Ilmu.

Tjiptono, F. \& Diana, A. (2003). Total quality manajemen, edisi revisi. Yogyakarta: Andi Offset.

Zamroni. (2007). Pendidikan dan demokrasi dalam transisi (prakondisi menuju era globalisasi). Jakarta: PSAP Muhammadiyah. 